\title{
Assessment of sustainable high temperature hydrogen production technologies
}

\section{Dorottya Guban*, Ibrahim Kolawole Muritala, Martin Roeb, Christian Sattler}

Institute of Solar Research, Deutsches Zentrum für Luft- und Raumfahrt (DLR)/German Aerospace Center, Linder Höhe, 51147, Köln, Germany

\section{H I G H L I G H T S}

- Today $85 \%$ of world's energy is fossil based; in future larger share for renewables.

- Using high temperature processes reduces the electricity demand.

- Most promising renewable ways: electrolysis, thermochemical cycles, BM gasification.

- Shift to renewable technologies in the long term scenario.

\section{A R T I C L E I N F O}

\section{Article history:}

Received 29 May 2019

Received in revised form

9 August 2019

Accepted 13 August 2019

Available online 28 September 2019

\section{Keywords:}

High temperature

Water electrolysis

Thermochemical cycles

Solar-to-hydrogen

Sustainable hydrogen production
G R A P H I C A L A B T R A C T

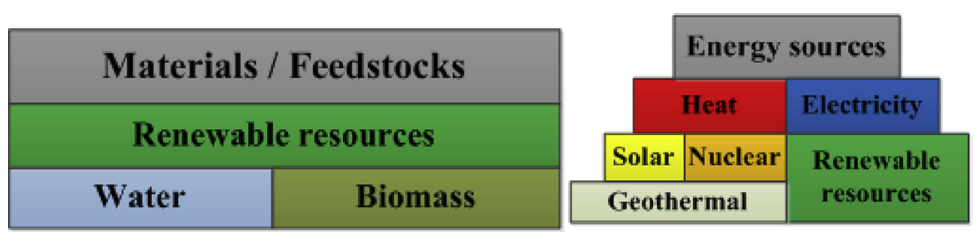

\footnotetext{
* Corresponding author.

E-mail address: dorottya.guban@dlr.de (D. Guban).
} 


\section{Introduction}

Research and technology development on hydrogen production have a major role in finding solutions to provide clean and alternative energy in order to ensure sustainable energy development. Hydrogen is one of the potential energy carriers for future energy [1,2], besides it is one of the most important feedstocks for production of chemicals, such as ammonia. While currently hydrogen is predominantly produced by fossil based processes, research and development have an increased interest in clear and sustainable solutions that in the future are expected contribute with a larger share to the production. This forecast is supported by the general trends in the energy market. As a confirmation of the shift towards sustainability in the energy market, Fig. 1 shows the world's total energy consumption by source for 1995 and 2017 with the projection of 2040 (estimated values) [3]. In 1995 and 2017 over $85 \%$ of the world primary energy originates from fossil based routes, but even during that period the share and total amount of energy from renewable sources increased significantly. This trend is expected to continue; in 2040 the share of renewables is foreseen to reach around $40 \%$. The limited reserves in fossil base resources have motivated the research and development on non-fossil based renewable resources aside their potentials in the gradual alleviation of economic dependence on hydrocarbons, the demand of hydrogen continues to increase daily in spite of the drawbacks that are faced with suitable hydrogen storage [4]. As a consequence this shift would have a major effect on the hydrogen production as well, and it supports technologies that are currently under development phase. Moreover, apart from the overall wider availability of renewable energy, there are several industrial processes that provide waste heat as well as renewable heat sources, such as concentrated sunlight, which can also be utilized to reduce the electricity demand of the hydrogen production process. The most promising non-fossil production routes are thermochemical methods, water electrolysis, renewable feedstocks reforming, photobiological water splitting methods, photoelectrochemical methods, and photocatalytic methods among others [2,5,6]. These production techniques are in different stages of their research and development, and each individual technique provides its own

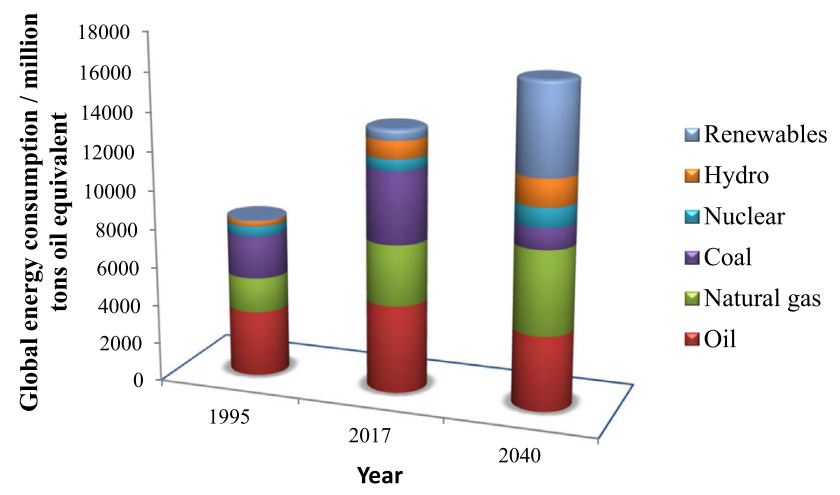

Fig. 1 - World's total energy consumption by source for the year 1995 and 2017 with forecast for the year 2040. unique opportunities, advantages, challenges and applicability [5].

Furthermore during the selection of the most suitable hydrogen production techniques the economical potentials have to be taken into account as well, especially in case of smaller scale decentralized plants [7]. This work focuses on technological options and assessment of the most promising, sustainable high temperature hydrogen production techniques.

\section{Major renewable feedstocks and energy sources for hydrogen production}

Hydrogen production routes can be categorized by two major aspects: the feedstocks and the energy sources. In case of truly renewable hydrogen both the feedstock and energy originates from renewable sources. The most abundant renewable hydrogen sources are water and biomass, which allow several different processing routes such as electrolysis, thermochemical decomposition, and gasification. The necessary energy can be provided in the form of electricity (e.g. in the electrolysis of water) or heat (e.g. for thermochemical processes). Both energy sources are available from any renewable and non-renewable sources. Fig. 2a, b summarizes the available feedstocks or materials and energy sources for hydrogen production, respectively. These feedstocks and energy sources shall be discussed in the following sections. This paper focuses on renewable or non-fossil resources for the production of hydrogen by means of high temperature technologies.

\section{Non-fossil routes options for hydrogen production}

\section{Water electrolysis}

Introduction, different methods

Water electrolysis is a viable way to produce truly green hydrogen regarding both the feedstocks and the energy source. It can be easily coupled with nuclear and renewable electricity sources. The three most well-known electrolysis methods are alkaline electrolysis (AE), polymer electrolyte membrane electrolysis (PEME) and solid oxide electrolysis (SOE), which are illustrated in Fig. 3(a), (b) and (c). AE is the oldest and most studied technology [8], in which an alkaline solution $(\mathrm{NaOH}$ or $\mathrm{KOH})$ is applied as an electrolyte. Alkaline electrolysers are commercially available from several companies (Hydrogenics, Uralkhimmash, AccaGen, Iht, Norsk Hydro etc.). Due to the relatively simple setup the technology is easy to scale-up, there are already existing plants up to the capacity of several megawatts. The disadvantage of the technology is its relatively low efficiency and low current density as well as the need for highly corrosive electrolyte [9]. The price of the electrolysers is highly dependent on the plant size; the price/kW installed capacity can vary with a factor of 10 [10].

The main advantage of the PEM electrolysers is their higher efficiency, but the noble metal catalyst is more sensitive to water impurities, and the Nafion ${ }^{\circledR}$ membrane electrolyte limits the maximum operating temperature to $\mathrm{T}<150^{\circ} \mathrm{C}[11]$. 


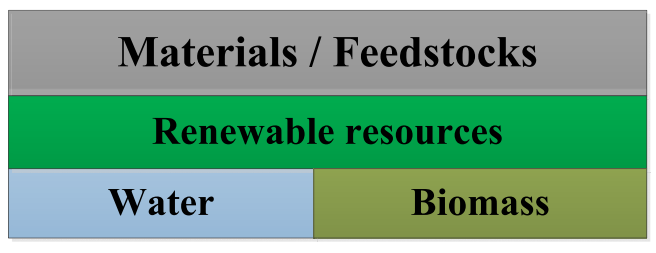

(a)

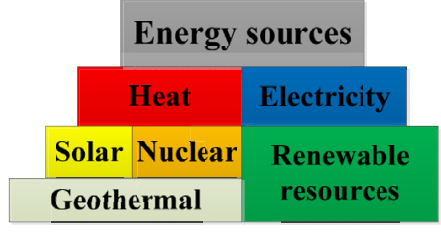

(b)

Fig. 2 - (a) Available renewable feedstocks for hydrogen production. (b) Renewable energy resources and energy sources for hydrogen production.
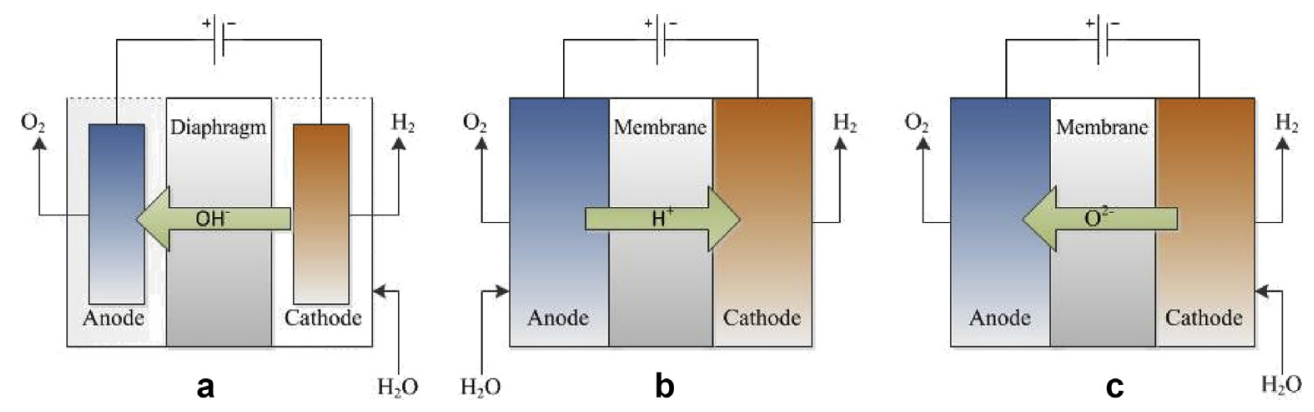

Fig. 3 - Scheme of hydrogen production methods by water electrolysis: a) alkaline electrolysis, b) polymer electrolyte membrane electrolysis and c) solid oxide electrolysis.

Furthermore, the feeding water has to be desalinized and demineralized before its contact with the MEA, which increases the energy demands of the overall process.

High temperature water electrolysis (HTE)

HTE processes can reach higher efficiencies than traditional low temperature electrolysis (LTE) mainly for two reasons; (i) part of the energy is supplied as heat with higher efficiency than electricity and (ii) the electrolysis itself is more efficient at higher temperatures due to the increased ionic conductivity of the solid oxide and enhanced reaction rates [12,13]. A case study by Badea et al. compared different hydrogen production plants utilizing HTE and LTE solutions with the target capacity of $100 \mathrm{kgH}_{2}$ /day [14]. Their technical analysis found that HTE is more favourable combined with concentrated solar radiation as a heat source. The majority of HTE research focuses on solid oxide electrolysis cells (SOEC), which are based on the same technology as the solid oxide fuel cell. One of the biggest advantages of SOE is due to the high operation temperature (700-900 ${ }^{\circ} \mathrm{C}$ ), which is not necessary to use noble metal catalysts, and efficiencies higher than $80 \%$ are achievable $[15,16]$. The ohmic losses in SOEC decrease while the electrode kinetics and electrode conductivity increase at higher operation temperature, which results in higher efficiencies. The water electrolysis is endothermic at high temperature, therefore SOE units can be integrated to thermal plants, such as solar or nuclear power plants or can run on electricity and utilize the available process heat.

The endothermic reaction that takes place in a SOEC is the reverse fuel cell reaction, where water is introduced to the cathode:
$2 \mathrm{H}_{2} \mathrm{O}+2 \mathrm{e}^{-} \rightarrow \mathrm{O}^{2-}+\mathrm{H}_{2}$

While $\mathrm{O}^{2-}$ ions transfer through the electrolyte to the anode, where the oxidation reaction takes place:

$\mathrm{O}^{2-} \rightarrow \frac{1}{2} \mathrm{O}_{2}+2 \mathrm{e}^{-}$

Resulting of the overall reaction

$\mathrm{H}_{2} \mathrm{O} \rightarrow \mathrm{H}_{2}+\frac{1}{2} \mathrm{O}_{2},=\mathrm{E}_{298 \mathrm{k}}^{0}=-1.229 \mathrm{~V}$

The efficiency of the cell (or stack) is defined as follows:

voltage efficiency=operating voltage/thermodynamic voltage

The thermodynamic voltage is calculated by using the Nernst equation and under standard conditions is $-1.229 \mathrm{~V}$. It is important to note that the thermodynamic voltage is temperature dependent; its actual value is lower at the higher operation temperatures of the SOEC. Under optimal conditions, the cell operates at the thermodynamic voltage, also called open circuit voltage without load.

In order to compare the hydrogen production efficiencies of different systems, the electrical efficiency is defined as:

electrical efficiency $=\mathrm{HHV}$ or LHV of produced $\mathrm{H}_{2} /$ used electricity

where HHV $=285.83 \mathrm{kJmol}^{-1}$ is the higher heating value and $\mathrm{LHV}=241.82 \mathrm{kJmol}^{-1}$ is the lower heating value of hydrogen at thermodynamic standard conditions, respectively. 


\section{Operation modes}

There are three possible operation modes for SOECs based on the operating voltage [17]:

(i) in endothermic mode the operating voltage is below the thermoneutral voltage, therefore external heat has to be applied;

(ii) in thermoneutral mode the operating voltage is the thermoneutral voltage, therefore the heat required equals to the heat produced by Joule effect, and temperature remains stable; and

(iii) in exothermic mode the operating voltage is above the thermoneutral voltage, therefore the temperature increases during operation.

The most desirable operation mode for a SOEC system is (ii), the constant thermoneutral voltage (or slightly above in order to account for potential heat losses) in order to ensure high efficiency and ease the heat management of SOEC stacks and systems [18].

Issues, technology readiness

The main hindrance of the market readiness of SOEC technology is its durability [19]. The cost estimations show a demand for lifetimes of at least 5-10 years, but today the SOFC technology has proven lifetimes of around 2 years. The stateof-art SOECs have nickel-yttria stabilized zirconia (Ni-YSZ) electrodes [20]. Studies show that there are several different degradation mechanisms, such as segregation of impurity phases to the triple phase boundary (TPB), poisoning of the YSZ by impurities from the feedstock, and oxygen electrode delamination or crack formation due to high oxygen activity at the electrode-oxygen interface. The degradation rate is also affected by the polarization rate and different operating conditions. Rao et al. [20] found that the degradation rate in both galvanostatic and potentiostatic operation is the highest in the first $200 \mathrm{~h}$ of testing, then the performance stabilizes over longer operation. During the long term testing the overpotential related degradation mechanisms do not occur in case of potentiostatic operation, since the voltage is kept constant, therefore more favourable than galvanostatic mode, where the overpotentials increased over time.

Generally, electrolysis is considered to be the most prominent alternative method for hydrogen generation that has already acquired a large market potential. Units in the MW scale are already available, and the issues concerning project manufacturing and supply chain development are being tackled as well. The 2020-2025 electrolysis is expected to become a competitive technology [21].

\section{Thermochemical cycles for hydrogen production}

Introduction, different methods

Thermochemical cycles utilizes a combination of chemical reactions driven by heat to thermochemically decompose water. The heat can be provided by different origins, therefore the potential to use renewable or waste heat of industrial processes to produce hydrogen as well as the achievable high thermal efficiencies make them a very attractive addition to the future energy mix. Thermochemical cycles have been investigated since the 1970s as possible hydrogen production technologies [22,23]; the several studied cycles can be categorized into two main groups:

- high temperature $\left(900-2000{ }^{\circ} \mathrm{C}\right)$ and

- low temperature $\left(300-700^{\circ} \mathrm{C}\right)$ cycles.

The lower temperatures can be provided by both nuclear and solar sources, while the higher temperatures above $900^{\circ} \mathrm{C}$ exceed the limitations of nuclear process heat. Although at higher temperatures the thermodynamics are more favourable, there are more technical and structural challenges to overcome due to the harsher environment.

Energy sources for thermochemical cycles

Apart from the fossil based energy sources, thermochemical cycles can be run by different alternativeand non-fossil energy providers as well. In high temperature gas cooled nuclear reactors the coolant temperature at the reactor exit is around 800 to $1000{ }^{\circ} \mathrm{C}$, the cooling fluid is usually helium. This temperature meets the requirements of several thermochemical cycles. The nuclear heat would allow a large scale hydrogen production plant as the commercial reactors are usually in the range of 3000 MWth [24].

Solar heat source can be utilized in the form of concentrated sunlight, which is able to provide higher temperatures up to $2000{ }^{\circ} \mathrm{C}$, allowing an even more flexible choice of the thermochemical cycle. The solution is also suitable for scaleup, the Dubai Electricity and Water Authority is currently developing a $700 \mathrm{MW}$ plant in the Mohammed bin Rashid Al Maktoum Solar Park that is expected to generate $5000 \mathrm{MW}$ total combined with PV by 2030 [25].

The thermal efficiency of thermochemical cycles is calculated as the ratio of HHV of produced hydrogen to the overall heat energy input.

Thermal efficiency $=\frac{\mathrm{HHV}_{\mathrm{H}_{2}}}{\left(\mathrm{Q}_{\text {heat }}+\mathrm{Q}_{\text {elec }}\right)}$

Types of thermochemical cycles

In the last decades hundreds of different thermochemical cycles were identified and analysed for water splitting. The main targets are closed loop systems, in which all the reactants are regenerated and recycled. The most studied and following ones are the sulphur-iodine cycle, hybrid sulphur cycle, and UT3 cycle. Metal/metal oxide cycles are also gaining more interest due to the cheap and durable solid redox materials that allows easy handling; therefore they are also included in this sub-section.

\section{(a) Sulphur-iodine cycle}

The sulphur-iodine (SI) or General Atomics process is a three step thermochemical process that results in dissociation of water into hydrogen and oxygen. The first step is the Bunsen reaction, in which water reacts with sulphur dioxide and iodine at around $120{ }^{\circ} \mathrm{C}$, to form sulphuric acid, $\mathrm{H}_{2} \mathrm{SO}_{4}$ and hydriodic acid (HI) $[26,27]$. 


$$
2 \mathrm{H}_{2} \mathrm{O}+\mathrm{SO}_{2}+\mathrm{xI}_{2} \rightarrow \mathrm{H}_{2} \mathrm{SO}_{4}+2 \mathrm{HI}_{\mathbf{x}}, \Delta \mathrm{G}_{400 \mathrm{~K}}^{0}=82 \mathrm{kJmol}^{-1}
$$

In the next step the sulphuric acid is decomposed in a twostage reaction, first to $\mathrm{SO}_{3}$ and then to $\mathrm{SO}_{2}$.

$\mathrm{H}_{2} \mathrm{SO}_{4} \rightarrow \mathrm{SO}_{3}+\mathrm{H}_{2} \mathrm{O}$

$\mathrm{SO}_{3} \rightarrow \mathrm{SO}_{2}+\frac{1}{2} \mathrm{O}_{2}$

The first step of the reaction takes place at around 400-500 ${ }^{\circ} \mathrm{C}$, whereas the second reaction occurs at temperatures above $800{ }^{\circ} \mathrm{C}$. However, it has been suggested that at least $1000{ }^{\circ} \mathrm{C}$ is needed for the SI process for improved sulphuric acid decomposition [28]. In the last step the polyhydriodic acid is decomposed to form hydrogen and iodine at temperatures higher than $300{ }^{\circ} \mathrm{C}[29,30]$.

$2 \mathrm{HI}_{\mathrm{x}} \rightarrow \mathrm{xI}_{2}+\mathrm{H}_{2}$

The process shown in Fig. 4 is a closed-loop system that operates with water feeding, hence only hydrogen and oxygen gases leave the system. All other reactants are sustained and recycled. This is one of the main advantages of the process, as it can run without any harmful emissions. At the same time it requires highly corrosive chemicals, therefore the reactor materials have to be carefully selected to avoid leakage or spilling.

Of all the reactions the $\mathrm{H}_{2} \mathrm{SO}_{4}$ decomposition requires the highest heat input; therefore it has the highest effect on the overall efficiency, which is currently below $50 \%$. Even though the process was intensively studied European projects as well as a General Atomics consortium; it still has not yet reached the breakthrough in the market.

(b) Hybrid-sulphur cycle

The hybrid-sulphur (HyS) cycle is a two stage thermoelectric process that uses high temperature heat to dissociate sulphuric acid into sulphur dioxide and oxygen, then the $\mathrm{SO}_{2}$ is re-oxidized by means of electrolysis and hydrogen is produced as shown in Fig. 5. The process was first suggested in
1974 by Brecher and Wu [31]. The high temperature step of the cycle is the sulphuricacid dissociation at $800-1100{ }^{\circ} \mathrm{C}$ in Eqn. (11) that is similar to the SI cycle. However, the re-oxidation of the $\mathrm{SO}_{2}$ is performed either by electrolysis or electrochemical oxidation. The most common method is PEM electrolysis, although the Nafion membrane limits the use of sulphuric acid with high concentrations. The reactions in the hybrid-sulphur cycle are [32]:

$\mathrm{H}_{2} \mathrm{SO}_{4} \rightarrow \mathrm{SO}_{3}+\mathrm{H}_{2} \mathrm{O}$

$\mathrm{SO}_{3} \rightarrow \mathrm{SO}_{2}+\frac{1}{2} \mathrm{O}_{2}$

$2 \mathrm{H}_{2} \mathrm{O}+\mathrm{SO}_{2} \rightarrow \mathrm{H}_{2} \mathrm{SO}_{4}+\mathrm{H}_{2}, \mathrm{E}_{298 \mathrm{~K}}^{0}(298 \mathrm{~K})=-0,158 \mathrm{~V}$

The presence of sulphur dioxide while performing electrolysis decreases the cell potential and hence the amount of electric energy needed to dissociate water into $\mathrm{H}_{2}$ and $\mathrm{O}_{2}$ also decreases and higher efficiencies can be achieved compared to the SI cycle [33]. The high temperature decomposition step can be performed at lower temperature with catalysts, although at higher temperature the kinetics are fast enough even without the use of catalyst. The thermal efficiencies are typically around $50 \%$.

(c) UT3 cycle

The UT3 $(\mathrm{Ca} / \mathrm{Fe} / \mathrm{Br})$ cycle (Fig. 6.) was developed at the University of Tokyo in 1978. It belongs to the low-temperature thermochemical cycles, suitable to be coupled with nuclear heat sources. The cycle comprises of four main steps [34]:

$\mathrm{CaO}+\mathrm{Br}_{2} \rightarrow \mathrm{CaBr}_{2}+1 / 2 \mathrm{O}_{2}, \Delta \mathrm{G}_{800 \mathrm{~K}}^{0}=-40.9 \mathrm{~kJ} \mathrm{~mol}-1$

$\mathrm{CaBr}_{2}+\mathrm{H}_{2} \mathrm{O} \rightarrow \mathrm{CaO}+2 \mathrm{HBr}, \Delta \mathrm{G}_{1000 \mathrm{~K}}^{0}=104.0 \mathrm{~kJ} \mathrm{~mol}-1$

$\mathrm{Fe}_{3} \mathrm{O}_{4}+8 \mathrm{HBr} \rightarrow 3 \mathrm{FeBr}_{2}+4 \mathrm{H}_{2} \mathrm{O}+\mathrm{Br}_{2}, \Delta \mathrm{G}_{500 \mathrm{~K}}^{0}$

$=-119.9 \mathrm{~kJ} \mathrm{~mol}-1$

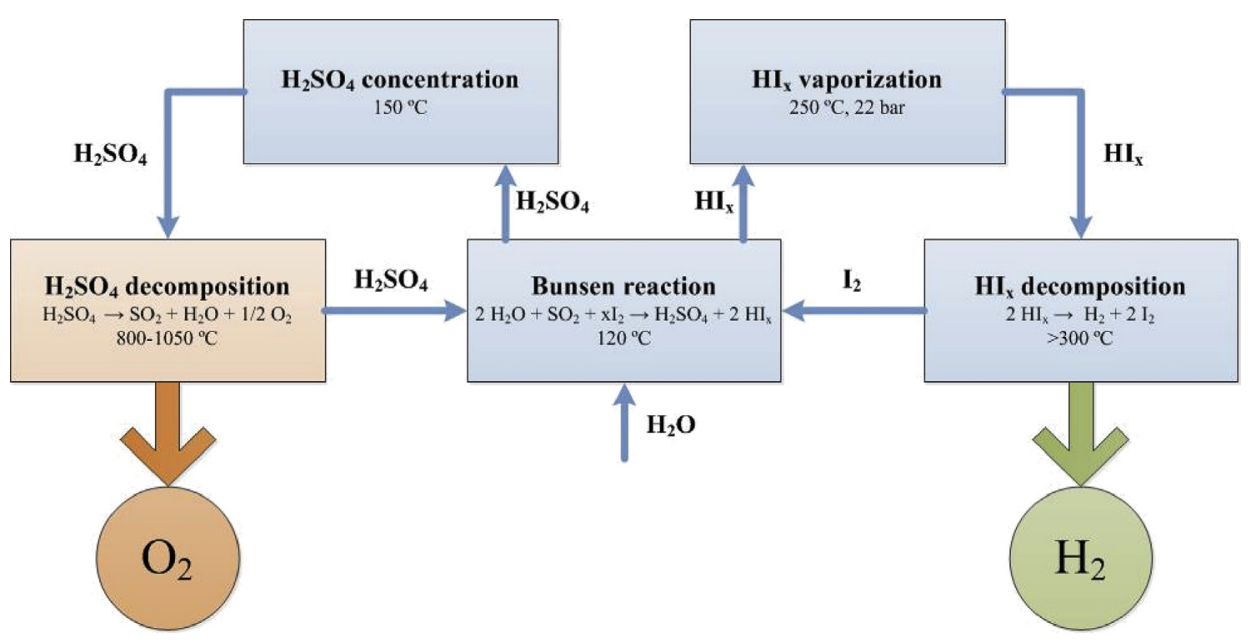

Fig. 4 - Scheme of the sulphur iodine cycle for hydrogen production. 


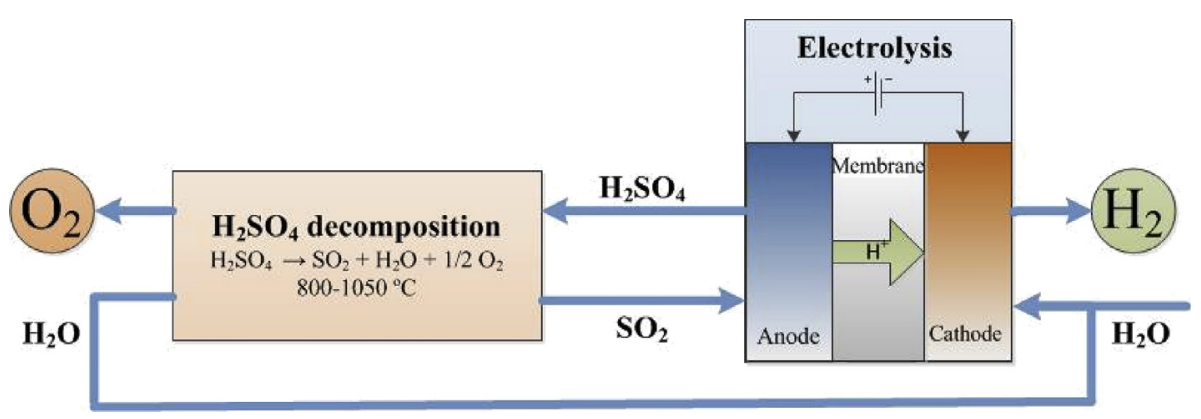

Fig. 5 - Scheme of the hybrid-sulphur process.

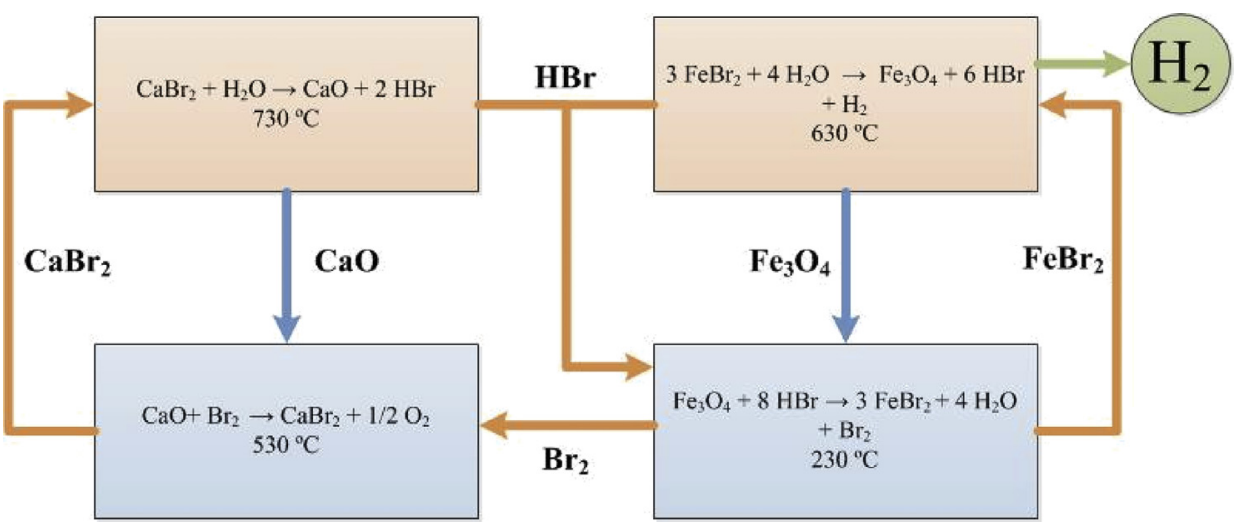

Fig. 6 - Schematic presentation of the UT3 cycle.

$3 \mathrm{FeBr}_{2}+4 \mathrm{H}_{2} \mathrm{O} \rightarrow \mathrm{Fe}_{3} \mathrm{O}_{4}+6 \mathrm{HBr}+\mathrm{H}_{2}, \quad \Delta \mathrm{G}_{900 \mathrm{~K}}^{0}$

$=117.5 \mathrm{~kJ} \mathrm{~mol}-1$

The process is widely studied on laboratory and pilot scale as well [35]. Despite its high efficiency (45\% thermal), the problems arising from sintering of the redox material, azeotropy and finding suitable structural materials hinders its industrial applications.

(d) Metal/metal oxide cycles

The achievable higher temperatures of Concentrated Solar Power (CSP) open the possibilities to use metal/metal oxide cycles for hydrogen productions. The two-step cycles can achieve high efficiencies, and the materials are less corrosive than the in case of the sulphur cycles. The redox material can be a multivalent metal (e.g. $\mathrm{Fe}_{3} \mathrm{O}_{4} / \mathrm{FeO}, \mathrm{CeO}_{2} / \mathrm{Ce}_{2} \mathrm{O}_{3}$ ), a metal oxide-metal pair $(\mathrm{ZnO} / \mathrm{Zn})$, or a metal oxide with oxygen nonstoichiometry (perovskites). The high temperature, therefore thermodynamically limiting step is the reduction of the oxidized form of the redox material, while the water splitting step takes place at lower temperatures. The process is illustrated by Fig. 7 , the reduction and oxidation steps are as follow:

$\mathrm{MO}_{(\mathrm{x}+\mathrm{y})} \rightarrow \mathrm{MO}_{\mathrm{x}}+\frac{\mathrm{y}}{2} \mathrm{O}_{2}$

$\mathrm{MO}_{\mathrm{x}}+\mathrm{yH}_{2} \mathrm{O} \rightarrow \mathrm{MO}_{(\mathrm{x}+\mathrm{y})}+\mathrm{yH}_{2}$

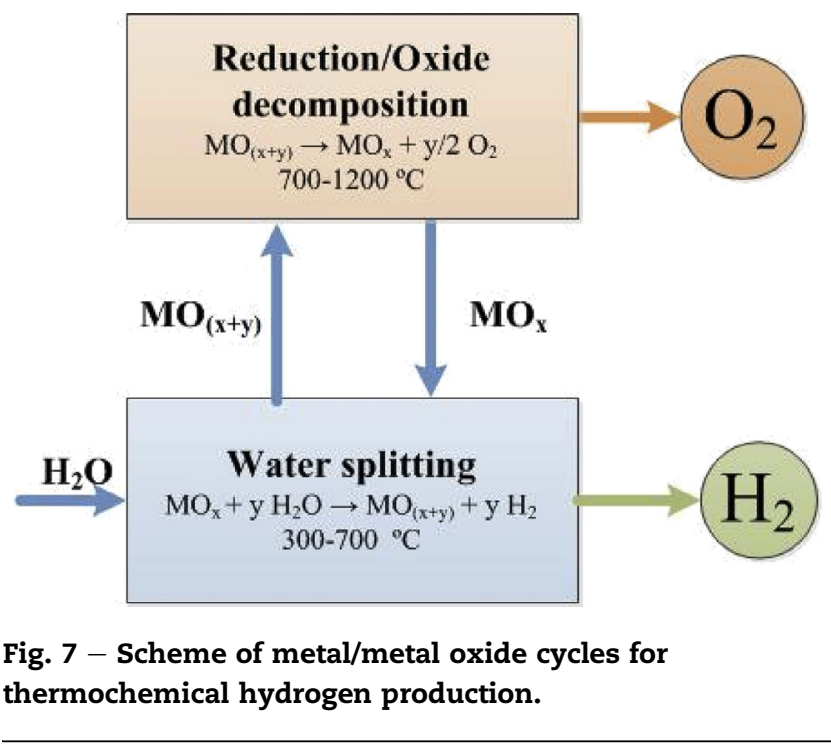

Even though the concept was proven up to the scale of 10 $\mathrm{kW}_{\text {th }}$, (reference) the technology has not yet reached the required technology readiness level to be introduced to the market.

Issues, technology readiness

Thermochemical cycles offer a promising alternative for hydrogen production, and if they reach a higher level of technology readiness they could have a reasonable share in the market. Currently they are still in the research phase, and 
they are facing common issues such as complex and expensive reactor design and harsh reaction conditions $(T, p$, corrosion), which are still yet to be overcome. The main challenge of the sulphur-iodine cycle is the separation of sulphuric acid from the hydrogen iodide without reversing the equilibria [36], moreover the corrosive environment requires an expensive reactor design. The hybrid sulphur cycle has improved efficiencies due to the use of catalyst, although a major part of the required energy is used to overcome the overpotentials due to mass transfer, reaction activation and ohmic resistance limitations [37]. Significant improvement could be achieved by improving the electrode materials. Metal/metal oxide cycles generally have low specific energy storage during reduction [38], which results in large material flows, and they many times require very high reduction temperatures. The UT-3 cycle is operated with solid reactants that raise the problem of solid handling and attrition; furthermore the melting point of the $\mathrm{Ca}-\mathrm{Br}_{2}$ limits the operation temperature at $760{ }^{\circ} \mathrm{C}$ [39]. The summary of the properties of the discussed thermochemical cycles is found in Table 1.

Overall, thermochemical cycles have the advantage that the process energy is mostly required in form of heat, hence

Table 1 - Summary of thermochemical cycles for hydrogen production.

\begin{tabular}{|c|c|c|c|}
\hline Process & $\begin{array}{c}\text { Redox cycle } \\
\text { (operation } \\
\text { conditions) }\end{array}$ & $\begin{array}{c}\text { Efficiency } \\
(\%)\end{array}$ & Pros and Cons \\
\hline \multirow[t]{2}{*}{$\begin{array}{l}\text { Sulphur } \\
\text { iodine } \\
\text { cycle }\end{array}$} & $\begin{array}{l}\mathrm{SO}_{2}-\mathrm{H}_{2} \mathrm{SO}_{4} \\
\left(800-900{ }^{\circ} \mathrm{C}\right)\end{array}$ & $42-51[24]$ & $\begin{array}{l}\text { Pros: } \\
\text { - closed cycle, no } \\
\text { harmful emissions. }\end{array}$ \\
\hline & & & $\begin{array}{l}\text { Cons: } \\
\text { - highly corrosive } \\
\text { environment, } \\
\text { - hydrogen-iodine } \\
\text { distillation }\end{array}$ \\
\hline \multirow[t]{2}{*}{$\begin{array}{l}\text { Hybrid- } \\
\text { sulphur } \\
\text { cycle }\end{array}$} & $\begin{array}{l}\mathrm{SO}_{2}-\mathrm{H}_{2} \mathrm{SO}_{4} \\
\left(800-1100^{\circ} \mathrm{C}\right)\end{array}$ & $41-53[40]$ & $\begin{array}{l}\text { Pros: } \\
\text { - integration of elec- } \\
\text { trolysis is possible, } \\
\text { - use of catalysts to } \\
\text { improve efficiency }\end{array}$ \\
\hline & & & $\begin{array}{l}\text { Cons: } \\
\text { scaling up }\end{array}$ \\
\hline \multirow[t]{2}{*}{$\begin{array}{l}\text { Metal/ } \\
\text { Metal } \\
\text { oxide } \\
\text { cycles }\end{array}$} & $\begin{array}{l}\mathrm{MeO}_{\mathrm{x}}-\mathrm{MeO}_{(\mathrm{x}+\mathrm{y})} \\
\left(1200-2000^{\circ} \mathrm{C}\right)\end{array}$ & $40-60[36]$ & $\begin{array}{l}\text { Pros: } \\
\text { - use of inexpensive } \\
\text { materials and renew- } \\
\text { able energy }\end{array}$ \\
\hline & & & $\begin{array}{l}\text { Cons: } \\
\text { - requires higher } \\
\text { temperatures }\end{array}$ \\
\hline \multirow[t]{2}{*}{ UT3 cycle } & $\begin{array}{l}\mathrm{CaO} \\
750^{\circ} \mathrm{C}\end{array}$ & $40[40]$ & $\begin{array}{l}\text { Pros: } \\
\text { - high efficiency, well- } \\
\text { studied process }\end{array}$ \\
\hline & & & $\begin{array}{l}\text { Cons: } \\
\text { - durability of solid } \\
\text { chemicals }\end{array}$ \\
\hline
\end{tabular}

they are interesting and valid options in regions where nuclear waste heat or high annual solar radiation is available. Currently they are in the development phase and expected to play a role in the hydrogen production mix only on the longer term.

\section{Biomass gasification}

Gasification of biomass is one of the commercially available technologies. Similar to coal gasification biomass is a widely available resource that comes from agriculture produce and waste, wood sawdust, food industry, municipal solid waste, communal waste and so on. These biomass resources are feedstock for the gasification process and they are expected to play a prominent role in the future renewable energy mix. The processes itself is a variation of pyrolysis based on partial oxidation of the used feedstock as biomass to produce mainly some amounts of $\mathrm{CO}, \mathrm{H}_{2}, \mathrm{CH}_{4}, \mathrm{CO}_{2}$ and $\mathrm{N}_{2}$ and char consisting of ash and unconverted organic compounds [41,42]. In general, biomass conversion mostly aims for syngas production. The reactor or gasifier chamber could be either a fixed bed or a fluidized bed reactor. Between both, the fluidized bed reactor offers better performance $[41,43]$. When biomass feedstock has some moisture contents, the gasification process may encounter some low thermal efficiency $[41,42,44]$. When the biomass is dried with superheated steams at about $900{ }^{\circ} \mathrm{C}$, higher yields of hydrogen is expected in the product gas [41,42]. Basic biomass gasification processes comprises of pyrolysis, partial oxidation and steam reforming, which are similar to those reactions discusses in sub-section 3.2. The general chemical formula for biomass is $\alpha \mathrm{C}_{l} \mathrm{H}_{m} \mathrm{O}_{n}$ and its conversion could be represented by the following reaction [45]:

$\alpha \mathrm{C}_{\mathrm{l}} \mathrm{H}_{\mathrm{m}} \mathrm{O}_{\mathrm{n}}+\beta \mathrm{H}_{2} \mathrm{O} \stackrel{\text { heat }}{\longrightarrow} \mathrm{aH}_{2}+\mathrm{bCO}+\mathrm{cCO}_{2}+\mathrm{dCH}_{4}+\mathrm{eC}+$ fTar

During the thermochemical conversion of biomass, some tar is present in the product gas composition at higher temperature of about $800-1000{ }^{\circ} \mathrm{C}$, which causes fouling and slugging effects on the gasifier facility [45]. The process may occur with or without catalyst. To upgrade the product gas, nickel catalysts are applied in a secondary reactor to clean up the gas [41]. Efficiencies of biomass gasification technology are usually in the range of $35 \%-50 \%[41,42]$. For more hydrogen production, $\mathrm{CH}_{4}$ and other hydrocarbon gases produced can be steam reformed and water gas shift by converting into $\mathrm{CO}_{2}$ and $\mathrm{H}_{2}$. With this technique, the desired hydrogen could be further purified with the aid of a pressure swing absorber unit.

\section{Issues, technology readiness}

The biomass gasification process is complex and sensitive and requires elaborate feeding and reactor units [46]. If renewable energy source is used, a major issue is the slow start-up of the process, which makes continuous operation more efficient, therefore the fluctuations and periodic nature of the energy source has to be overcome by storage solutions. The quality and purity of the product can vary widely; as a consequence a purification unit is also essential. Nonetheless, several large scale demonstration projects $[47,48]$ have been successfully 
conducted, and the technology is commercially available. It is considered to be an important, decentralized hydrogen generation method for smaller scale, local production.

\section{Conclusion and future outlook for hydrogen production}

Although policies and long term strategies favour hydrogen production from renewable sources, due to the lack of maturity of the available renewable technologies, hydrogen is produced predominantly by using fossil fuels. At the same time fossil production routes can be coupled with $\mathrm{CO}_{2}$ capture and sequestration (CCS), which leads to a cheap and greenhouse gas emission free approach for the transition period towards renewables. Electrolysis technology is currently limited by the durability of the systems, but due to the intensive research these problems are expected to be overcome in the next decades, and the feasibility will depend on the price of the necessary renewable electricity. Water electrolysis is already in the scope of the industry, and the cost and lifetime of SOEC systems are expected to decrease in the next decade and by 2030 it is likely to reach the level of AEC and PEMEC [49], although these prospects include high uncertainties. Thermochemical cycles have the advantage of converting the energy of the heat source (concentrated sunlight or nuclear waste heat) directly; therefore the efficiency is not limited by electricity conversion, although the solar energy conversion itself is still very low. In the next ten years they are not expected to have a significant market share, but on the long term, if the technology matures by successful research and demonstration projects, it can be a valid option in regions where high solar radiation is available. Biomass gasification is an emerging technology that has the potential to provide hydrogen at a low price in smaller quantities, but the scaling-up to large, centralized production is foreseen only on a long-term scenario.

In general each technology has its own advantages and disadvantages, and each of them could have its share in the future energy mix. The choice of the most suitable hydrogen production route is strongly influenced by the geo-economical characteristics of the countries, such as the price of fossil fuels, carbon, and the availability of renewable resources. The natural conditions available in the different regions, such as water, annual solar irradiance [50], on- and offshore wind [51], and geothermal energy varies widely; furthermore the most suitable locations for renewable plants may not coincide with the current conventional power plants. Areas, where cheap natural gas is available are expected to still rely on it with CCS, while for regions where renewable energy is widely accessible the shift towards green electricity or heat is an appealing option already in the mid-term. Both ways are suitable to provide hydrogen without GHG emission, and therefore supports the development of the hydrogen infrastructure in a mid-term scenario.

\section{REFEREN C E S}

[1] Dufour J, Serrano DP, Gálvez JL, Moreno J, González A. Hydrogen production from fossil fuels: life cycle assessment of technologies with low greenhouse gas emissions. Energy Fuels 2011;25(5):2194-202. https://doi.org/10.1021/ef200124d.

[2] Shell Deutschland Oil GmbH. Shell hydrogen study. Energy of the future? Sustainable mobility through fuel cells and $\mathrm{H} 2$ with assistance of Shell and Wuppertal Institut. Hamburg. Available online at: https://www.shell.de/medien/shellpublikationen/shell-hydrogen-study.html\#vanityaHR0cHM6Ly93d3cuc2hlbGwuZGUvaDJzdHVkeQ; 2017.

[3] BP Energy Outlook. Available online at: https://www.bp.com/ content/dam/bp/business-sites/en/global/corporate/pdfs/ energy-economics/energy-outlook/bp-energy-outlook-2019. pdf; 2019.

[4] Boudries R. Techno-economic study of hydrogen production using CSP technology. Int J Hydrogen Energy

2018;43(6):3406-17. https://doi.org/10.1016/ j.ijhydene.2017.05.157.

[5] Riis T, Hagen EF, Vie PJS, Ulleberg $\varnothing$. Hydrogen production and storage. R\&D priorities and gaps. Paris, France: International Energy Agency (IEA); 2006. Available online at: https://webstore.iea.org/hydrogen-production-and-storage.

[6] Wang Y, Zhang S. Economic assessment of selected hydrogen production methods: a review. Energy Sources B Energy Econ Plan Policy 2017;12(11):1022-9. https://doi.org/ 10.1080/15567249.2017.1350770.

[7] Yang C, Ogden JM. Renewable and low carbon hydrogen for California - modeling the long term evolution of fuel infrastructure using a quasi-spatial TIMES mode. Int J Hydrogen Energy 2013;38(11):4250-65. https://doi.org/ 10.1016/j.ijhydene.2013.01.195.

[8] Trasatti S. Water electrolysis: who first? J Electroanal Chem 1999;476:90-1. https://doi.org/10.1016/S0022-0728(99)003642.

[9] Balat M. Potential important of hydrogen as a future solution to environmental and transportation problems. Int J Hydrogen Energy 2008;33(15):4013-29. https://doi.org/ 10.1016/j.ijhydene.2008.05.047.

[10] Jensen JO, Bandur V, Bjerrum NJ, Jensen SH, Ebbesen S, Mogensen M, Tophøj N, Yde L. Pre-investigation of water electrolysis. PSO-F\&U; 2008. no. 2006-1-6287, http:// ieahydrogen.org/Activities/National-Documents/Task-18/ electrolysis-NEI-DK-5057.aspx. Available online at:.

[11] Su H, Bladergroen BJ, Pasupathi S, Linkov V, Ji S. Performance investigation of membrane electrode assemblies for hydrogen production by solid polymer electrolyte water electrolysis. Int J Electrochem Sci 2012;7:4223-34. https:// doi.org/10.20964/2018.12.84.

[12] Ganley JC. High temperature and pressure alkaline electrolysis. Int J Hydrogen Energy 2009;34(9):3604-11. https://doi.org/10.1016/j.ijhydene.2009.02.083.

[13] Todd D, Schwager M, Mérida W. Thermodynamics of hightemperature, high-pressure water. J Power Sources 2014;269:424-9. https://doi.org/10.1016/ j.jpowsour.2014.06.144.

[14] Badea G, Naghiu GS, Giurca I, Așchilean I, Megyesi E. Hydrogen production using solar energy - technical analysis. Energy Procedia 2017;112:418-25. https://doi.org/10.1016/ j.egypro.2017.03.1097.

[15] Fujiwara S, Kasai S, Yamauchi H, Yamada K, Makino S, Matsunaga K, Yoshino M, Kameda T, Ogawa T, Momma S, Hoashi E. Hydrogen production by high temperature electrolysis with nuclear reactor. Prog Nucl Energy 2008;50:4222-6. https://doi.org/10.1016/ j.pnucene.2007.11.025.

[16] Li Q, Zheng Y, Guan W, Jin L, Xu C, Wang WG. Achieving high-efficiency hydrogen production using planar solidoxide electrolysis stacks. Int J Hydrogen Energy 2014;39(21):10833-43. https://doi.org/10.1016/ j.ijhydene.2014.05.070. 
[17] Godula-Jopek A. Hydrogen production: by electrolysis. Wiley/ VCHH; 2015. ISBN-13: 978-3527333424.

[18] Chen M, Sun X, Chatzichristodoulou C, Koch S, Hendriksen PV, Bjerg Mogensen M. Thermoneutral operation of solid oxide electrolysis cells in potentiostatic mode. ECS Transactions 2017;78(1):3077-88. https://doi.org/10.1149/ 07801.3077 ecst.

[19] Zhang X, O'Brien JE, Brien RCO, Hartvigsen JJ, Tao G, Housley GK. Improved durability of SOEC stacks for high temperature electrolysis. Int J Hydrogen Energy 2013;38(1):20-8. https://doi.org/10.1016/ j.ijhydene.2012.09.176.

[20] Rao M, Sun X, Hagen A. A comparative study of durability of solid oxide electrolysis cells tested for Co-electrolysis under galvanostatic and potentiostatic conditions. J Electrochem Soc 2018;10(165):F748-55. https://doi.org/10.1149/ 2.0151810jes.

[21] Thomas D, De Lhoneux A. Best-in class PEM water electrolysis for renewable ammonia production. In: NH3 event conference; 2019 [Rotterdam, NL].

[22] Lewis MA, Masin JG, O'Hare PA. Evaluation of alternative thermochemical cycles Part I: the methodology. Int J Hydrogen Energy 2009;34(9):4115-24. https://doi.org/10.1016/ j.ijhydene.2008.06.045.

[23] Bhosale RR, Takalkar G, Sutar P, Kumar A, AlMomami F, Khaisheh M. A decade of ceria based solar thermochemical $\mathrm{H}_{2} \mathrm{O} / \mathrm{CO}_{2}$ splitting cycle. Int J Hydrogen Energy 2019;44(1):34-60. https://doi.org/10.1016/ j.ijhydene.2018.04.080.

[24] Wrochna G, Sobolewski J. Possibilities for deployment of high-temperature nuclear reactors in Poland. Warsaw: Report of Ministry of Energy; 2017. http://www.snetp.eu/wpcontent/uploads/2018/06/HTR-Report-Ministry-of-EnergyPoland.pdf.

[25] Dubai Electricity \& Water Authority. Mohammed bin Rashid Al Maktoum solar Park brochure. Government of Dubai; 2018. Available online at: https://www.dewa.gov.ae/en/customer/ innovation/renewable-energy/mohammed-bin-rashid-almaktoum-solar-park.

[26] Shriniwas Rao A, Sujeesh S, Nafees Ahmed V, Fani HZ, Tewari PK, Gantayet LM. Study of effect of high pressures and elevated temperatures on Bunsen reaction of Iodine-Sulfur thermo-chemical process. Int J Hydrogen Energy 2017;40(15):5025-33. https://doi.org/10.1016/ j.ijhydene.2015.02.092. 2017.

[27] Hadj-Kali MK, Gerbaud V, Lovera P, Baudouin O, Floquet P, Joulia X, Borgard J-M, Carles P. Bunsen section thermodynamic model for hydrogen production by the sulfur-iodine cycle. Int J Hydrogen Energy 2009;34(16):6625-35. https://doi.org/10.1016/ j.ijhydene.2009.06.022.

[28] Huang C, T-Raissi A. Analysis of sulfur-iodine thermochemical cycle for solar hydrogen production. Part I: decomposition of sulfuric acid. Sol Energy 2005;78(5):632-46. https://doi.org/10.1016/j.solener.2004.01.007.

[29] Ying Z, Zheng X, Zhang Y, Cui G. Development of a novel flowsheet for sulfur-iodine cycle based on the electrochemical Bunsen reaction for hydrogen production. Int J Hydrogen Energy 2017;42(43):26586-96. https://doi.org/ 10.1016/j.ijhydene.2017.09.035.

[30] Klett AS, Mena SE, Bruce DA, Thies MC. Liquid-liquid equilibrium tie-line compositions at elevated temperatures and pressures for the $\mathrm{I} 2-\mathrm{H} 2 \mathrm{O}$ and $\mathrm{HI}-\mathrm{I} 2-\mathrm{H} 2 \mathrm{O}$ systems of the Sulfur-Iodine Cycle. Int J Hydrogen Energy 2012;37(20):15020-8. https://doi.org/10.1016/ j.ijhydene.2012.08.005.

[31] E Brecher L, K Wu C. Electrolytic decomposition of water. United States Patent US3888750A; 10 June 1975.
[32] Gorensek MB, Staser JA, Stanford TG, Weidner JW. A thermodynamic analysis of the $\mathrm{SO} 2 / \mathrm{H} 2 \mathrm{SO} 4$ system in SO2depolarized electrolysis. Int J Hydrogen Energy 2009;34(15):6089-95. https://doi.org/10.1016/ j.ijhydene.2009.06.020.

[33] Kaur H, Wang M, Gorensek MB, Chen C-C. Thermodynamic modeling of the hybrid sulfur (HyS) cycle for hydrogen production. Fluid Phase Equilib 2018;460:175-88. https:// doi.org/10.1016/j.fluid.2017.12.025.

[34] Sakurai M, Miyake N, Tsutsumi A, Yoshida K. Analysis of a reaction mechanism in the UT-3 thermochemical hydrogen production cycle. Int J Hydrogen Energy 1996;21(10):871-5. https://doi.org/10.1016/0360-3199(96)00029-8.

[35] Lemont F, Lafon C, Dedryvere R, Gonbeau D. Physicochemical and thermodynamic investigation of the UT-3 hydrogen production cycle: a new technological assessment. Int J Hydrogen Energy 2006;31(7):906-18. https:// doi.org/10.1016/j.ijhydene.2005.07.011.

[36] Kar S, Bindal RC, Prabakar S, Tewari PK, Ramanathan S, Nuwad Jeetendra, Pillai CGS. Membrane development for applications in hydrogen production using the sulphuriodine thermochemical route. Int J Nucl Hydrog Prod Appl 2011;2(3):227-36. https://doi.org/10.1504/ IJNHPA.2011.038345.

[37] Jung YH, Shin BS, Jeong YH. Nuclear hydrogen production by the $\mathrm{SO}_{2}$ depolarized water electrolysis using PEMFC. In: Proceedings of the 41th. KNS regular general meeting and autumn conference, reactor SystemTechnology, PyongChang, Korea Oct. 29-31; 2008.

[38] a. Bulfin B, Vieten J, Agrafiotis C, Roeb M, Sattler C. Applications and limitations of two step metal oxide thermochemical redox cycles; a review. J Mater Chem 2017;5(36):18951-66. https://doi.org/10.1039/C7TA05025A[xx]. b. Goswami N, Kar S, Bindal RC, Tewari PK. A review of thermochemical cycles for hydrogen production: analysis of potential of membrane technology in I-S, UT-3 and CuCl cycles. Int J Nucl Hydrog Prod Appl 2013;2(4):282-316. https:// doi.org/10.1504/ijnhpa.2013.057333.

[39] National Research Council and National Academy of Engineering. The hydrogen economy: opportunities, costs, barriers, and R\&D needs. Washington, DC: The National Academies Press; 2004. https://doi.org/10.17226/10922.

[40] Stolten D. Hydrogen and fuel cells fundamentals, technologies and applications. Wiley-VCH; 2010, ISBN 978-3527-32711-9.

[41] Holladay JD, Hu J, King DL, Wang Y. An overview of hydrogen production technologies. Catal Today 2009;139(4):244-60. https://doi.org/10.1016/j.cattod.2008.08.039.

[42] El-Shafie M, Kambara S, Hayakawa Y. Hydrogen production technologies overview. J Power Energy Eng 2019;7(1):107-54. https://doi.org/10.4236/jpee.2019.71007.

[43] Asadullah M, Ito S, Kunimori K, Yamada M, Tomishige K. Energy efficient production of hydrogen and syngas from biomass: development of low-temperature catalytic process for cellulose gasification. Environ Sci Technol 2002;36(20):4476-81. https://doi.org/10.1021/es020575r.

[44] Yamada O. Generation of hydrogen gas by reforming biomass with superheated steam. Thin Solid Films 2006;509(1-2):207-11. https://doi.org/10.1016/ j.tsf.2005.09.174.

[45] Dincer I, Acar C. Review and evaluation of hydrogen production methods for better sustainability. Int J Hydrogen Energy 2015;40(34):11094-111. https://doi.org/10.1016/ j.ijhydene.2014.12.035.

[46] Bridgewater AV. The future for biomass pyrolysis and gasification: status, opportunities and policies for Europe. Altener report; 2002. https://ec.europa.eu/energy/sites/ener/ files/documents/2002_report_p536.pdf. 
[47] Furutani Y, Norinage K, Kudo S, Hayashi J, Watanabe T. Current situation and future scope of biomass gasification in Japan. EVERGREEN Joint J Nov Carbon Resour Sci Green Asia Strategy 2017;4(4):24-9. https://doi.org/10.5109/1929681.

[48] International Energy Agency. Biomass gasification in the United States, country report for IEA bioenergy task 33. 2013. http://task33.ieabioenergy.com/download.php?file=files/file/ country_reports/2015/USA2015.pdf.

[49] Schmidt O, Gambhir A, Staffel I, Hawkes A, Nelson J, Few S. Future cost and performance of water electrolysis: an expert elicitation study. Int J Hydrogen Energy 2017;42(52):30470-92. https://doi.org/10.1016/j.ijhydene.2017.10.045.

[50] Lewis NS, Nocera DG. Powering the planet: chemical challenges in solar energy utilization. Proc Natl Acad Sci U S A 2007;103:15729-35. https://doi.org/10.1073/ pnas.0603395103.

[51] International Energy Agency. Wind power technology roadmap. https://webstore.iea.org/technology-roadmapwind-energy-2013; 2013. 